\title{
Premonitory symptoms of Feeding and Eating Disorders in pediatric age
}

\author{
Giampaolo De Luca ${ }^{1 *}$, Matteo Napoletani \\ From 71st Congress of the Italian Society of Pediatrics. Joint National Meeting SIP, SIMGePeD, Study Group \\ on Pediatric Ultrasound, SUP Study Group on Hypertension \\ Rome, Italy. 4-6 June 2015
}

Feed and Eating Disorders (FED), whose diagnostic criteria have recently been modified in the DSM-5 [1], are multifactorial diseases caused by complex interactions between biological, psychological and social factors $[2,3]$, whose frequency is sharply increasing in adolescence [4-6].

The diagnosis is complex, especially in early adolescence (8-12 years), because of the extreme heterogeneity of symptomatic expressions, which doesn't allow a precise nosographic assignment [3,7-9]. The consequent diagnostic delay has a negative influence on the course of treatment and prognosis, making recoveries less and less frequent [10-12].

The role of the Family Pediatrics is, therefore, essential to intercept, through simple diagnostic tests (such as EAT 26) the first signs of these conditions because from this depends on the subsequent diagnosis, therapy and prognosis [13-18] (Table 1).

The first task is to suspect a FED and to assess the differential diagnosis or comorbidity with other organic or mental diseases [2,3,6,19-21] (Table 2).

The second task is to assess the severity of the problem for both organic [22] and psychic aspects, in order to formulate an operational program sustainable and shareable with the family and establish the urgency of sending the patient to the specialist and the type of taking charge (outpatient or inpatient).

We propose to distinguish three steps of increasing severity, with which FED may present themselves to the observation of the family pediatrician: the suspect, the diagnosis, the emergency.

The suspect, includes those patients who have just embarked on dangerous or insane practices to lose

\footnotetext{
* Correspondence: giampaolo60@libero.it

${ }^{1}$ Pediatra di famiglia, Studio Medico Pediatrico, Amantea (CS), 87032, Italy
}

Full list of author information is available at the end of the article
Table 1. The most significant questions in suspicion of FED among adolescent. Traits items of EAT-26 which correlate with positive total scores

\begin{tabular}{l} 
"How many diets have you begun in last year? \\
"Do you think, you should be on diet?" \\
"Do you feel dissatisfied of the weight of your body?" \\
\hline
\end{tabular}

Table 2. Differential diagnosis with other organic diseases

\begin{tabular}{l}
\hline Endocrine: hyperthyroidism, diabetes mellitus, Addison's disease, \\
Simmonds syndrome \\
\hline Gastrointestinal: achalasia, celiac disease, chronic inflammatory bowel \\
disease, giardiasis and other malabsorption \\
\hline Gynecological: pregnancy, other causes of amenorrhea \\
\hline Infectious: AIDS, fungal infections, tuberculosis, subacute bacterial \\
endocarditis \\
\hline Neoplastic: meningiomas and any type of malignant tumor \\
\hline Drugs: amphetamine, thyroid hormones, antidepressants, tricyclic, \\
neuroleptics, lithium
\end{tabular}

weight without falling in any of the diagnostic categories of DMS-5 [1]. These patients need an educational intervention that can be done by the pediatrician (Table 3).

The diagnosis, includes cases that fully meet the diagnostic criteria of DMS-5 [1], without showing signs of serious and immediate biological or psychological risk. Such patients can be initially helped through the motivational interviewing [23] and subsequently entrusted to a multidisciplinary team, which also takes care of the family, promoting inter and intra-family relationship [11,24].

The emergency, includes patients in serious condition for which is indicated urgently indicated a taking in 
Table 3. Educational Intervention by the family pediatrician (Heath budget for FED). Valuations/ informations relative to the following items

\begin{tabular}{l}
\hline Balanced nutrition and health \\
\hline Caloric needs \\
\hline Satisfaction of the body image \\
"Necessary" and "dangerous" food \\
Using compensation mechanisms to bingeing (vomiting, compulsive \\
motor activity), \\
\hline Use of drugs \\
\hline Family, social, emotional relations
\end{tabular}

Table 4. The indications of hospitalization

\section{Biological decompensation}

(includes all the serious organic conditions)

a. Serious weight loss (25-40\%)

b. Rapidly evolutive weight loss

c. Total refusal of food

d. Serious complications of malnutrition as syncopations, convulsions, cardiac arrhythmias or congestive heart failure, dehydration, acrocyanosis, instability of physiological parameters (Systolic Blood Pressure $\leq 90 \mathrm{mmHg}$, Heart Rate $\leq$ $40 / \mathrm{min}$, body temperature $\leq 36^{\circ} \mathrm{C}$ )

II. Psychological decompensation

(includes all high risk situations and the psychiatric comorbidities)

a. Suicide attempts

b. Self-mutilations

c. Abuse of drugs or other substances

d. Severe depression

e. Anxiety

f. Obsessive-compulsive personality disorder Borderline personality disorder

g. Sexual or physical abuse.

III. Other situations

a. Failure of outpatient treatment, after attempt of 2-3 months without any modifications in the clinical picture

b. Problematic family situation

c. Request from the patient or from his family

charge by a multi-professional team, possibly with an ICU admission, inpatient or outpatient (Table 4).

Since drop-out and relapses are frequent in the course of the FED [25] remains to the pediatrician to assess the progress of the disease and the outcome of care, to manage over time any residual symptoms or relapses or even new emergencies.

\section{Authors' details}

${ }^{1}$ Pediatra di famiglia, Studio Medico Pediatrico, Amantea (CS), 87032, Italy. ${ }^{2}$ Studente in medicina, Sapienza Università di Roma, Roma (RM), 00185, Italy.

Published: 30 September 2015

\section{References}

1. American Psychiatric Association: Feeding and Eating Disorders. Diagnostic and Statistical Manual of Mental Disorders. 5 edition. Washington: American Psychiatric Publishing; 2013, 329-354, DSM-5.

2. Brooks SJ, Rask-Andersen M, Benedict C, Schiöth HB: A debate on current eating disorders diagnoses in light of neurobiological findings: is it time for a spectrum model? BMC Psychiatry 2012, 12-76.
3. Dalla Ragione L: I disturbi del comportamento alimentare: un epidemia della modernità. In: Presidenza del Consiglio dei Ministri, Dipartimento della Gioventù. II coraggio di guardare: prospettive ed incontri per la prevenzione dei disturbi del comportamento alimentare. Eye 03 Roma 2012, 19-34.

4. Powers PS, Santana CA: Eating disorders: a guide for the primary care physician. Prim Care 2002, 29:81-98.

5. Favero A, Caregaro L, Tenconi E, Bosello R, Santonastaso P: Time trends in age at onset of anorexia nervosa and bulimia nervosa. J Clin Psychiatry 2009, 70:1715-21.

6. Dalle Grave R: Eating disorders: progress and challenges. Eur J Int Med 2001, 22:153-60

7. Lask B, Bryant-Waugh R, Wright F, Campbell M, Willoughby K, Waller G: Family physician consultation patterns indicate high risk for early-onset anorexia nervosa. Int J Eat Disord 2005, 38:269-72.

8. Sigel E: Eating disorders. Adolesc Med 2008, 19:547-72

9. Centers for Disease Control and Prevention (CDC), Eaton DK, Kann L, Kinchen S, Shanklin Flint KH, Hawkins J, et al: Youth risk behavior surveillance - United States, 2011. MMWR Surveill Summ 2012, 61:1-162.

10. American Academy of Pediatrics, Committee on Adolescence: Identification and management of eating disorders in children and adolescents. Pediatrics 2010, 126:1240-53.

11. Nicholls D, Hudson D, Mahomed F: Managing anorexia nervosa. Arch Dis Child 2011, 96:977-82.

12. Maestro S, Baroncelli Gl, Ghione S, Bertelloni S: I disturbi del comportamento alimentare in adolescenza. Prospettive in pediatria 2013, 170:74-83

13. Martin $\mathrm{H}$, Ammerman SD: Adolescents with eating disorders. Primary care screening, identification, and early intervention. Nurs Clin North Am 2002, 37:537-551.

14. Yamamoto C, Uemoto M, Shinfuku N, Maeda K: The usefulness of body image tests in the prevention of eating disorders. J Med Sci 2007, 53:79-91.

15. Johnston O, Fornai G, Cabrini S, Kendrick T: Feasibility and acceptability of screening for eating disorders in primary care. Fam Pract 2007, 24:511-7.

16. Engelsen BK, Hagtvet KA: A generalizability study of the Eating Attitudes Test (EAT-12) in non clinical adolescents. Eating and Weight Disord 1999, 4:179-186.

17. Anstine $D$, Grinenko D: Rapid screening for disordered eating in collegeaged females in the primary care setting. J Adolesc Health 2000, 26:338-342.

18. Garner DM, Olmsted MP, Bohr Y, Garfinkel PE: The eating attitudes test: psychometric features and clinical correlates. Psychol Med 1982, 12:871-8.

19. Winston AP, Barnard D, D'Souza G, Shad A, Sherlala K, Sidhu J, et al: Pineal germinoma presenting as anorexia nervosa: Case report and review of the literature. Int J Eat Disord 2006, 39:606-8.

20. Crawford JR, Santi MR, Vezina G, Myseros JS, Keating RF, LaFond DA, et al: CNS germ cell tumor (CNSGCT) of childhood: presentation and delayed diagnosis. Neurology 2007, 68:1668-73.

21. Andreu Martínez FJ, Martínez Mateu JM: Intracranial germ cell tumor mimicking anorexia nervosa. Clin Transl Oncol 2006, 8:915-8.

22. Cole TJ, Flegal KM, Nicholls D, Jackson AA: Body mass index cut offs to define thinness in children and adolescents: international survey. $B M J$ 2007, 28(335):194.

23. Miller W, Rollnick S: Motivational Interviewing: Helping People Change. New York: The Guilford Press: 32012.

24. Watson HJ, Bulik CM: Update on the treatment of anorexia nervosa: review of clinical trials, practice guidelines and emerging interventions. Psychol Med 2011, 10:1-24.

25. Steinhausen HC, Boyadjieva S, Griogoroiu-Serbanescu M, Neumärker KJ: The outcome of adolescent eating disorders. Eur Child Adolesc Psychiatry 2003, 12:91-98.

doi:10.1186/1824-7288-41-S2-A25

Cite this article as: De Luca and Napoletani: Premonitory symptoms of Feeding and Eating Disorders in pediatric age. Italian Journal of Pediatrics 2015 41(Suppl 2):A25. 